\title{
HUBUNGAN POLA ASUH AUTORITATIF DENGAN TARAF KECEMASAN PADA SISWA AKSELERASI SMA NEGERI 1 DENPASAR
}

\author{
Amanda Sari dan Dr. I Made Rustika, M.Si., Psi \\ Program Studi Psikologi, Fakultas Kedokteran, Universitas Udayana \\ miaamandasari@gmail.com
}

\begin{abstract}
Abstrak
Kecemasan merupakan keadaan tegang yang berlebihan tidak pada tempatnya, yang ditandai oleh perasaan khawatir, tidak menentu ataupun takut. Kecemasan mampu mempengaruhi kesehatan dan perkembangan emosi, sehingga sangat berperan dalam kehidupan seseorang, lebih-lebih lagi pada siswa kelas akselerasi yang selalu dituntut berprestasi tinggi. Pola asuh yang diterapkan oleh orang tua sangat menentukan kemampuan remaja dalam beradaptasi dengan berbagai permasalahan. Penerapan pola asuh autoritatif yang ditandai oleh kehangatan hubungan orangtua dengan anak akan sangat mempengaruhi kemampuan remaja dalam mengatasi permasalahan emosional.

Penelitian ini bertujuan untuk mengetahui hubungan antara pola asuh autoritatif dengan taraf kecemasan siswa akselerasi. Subjek dalam penelitian ini adalah semua siswa akselerasi SMA Negeri 1 Denpasar. Instrumen yang dipergunakan dalam penelitian ini adalah skala pola asuh autoritatif dan skala kecemasan.

Data penelitian dianalisis dengan teknik product moment. Koefisien korelasi antara pola asuh autoritatif dengan taraf kecemasan adalah $-0,268(\mathrm{p}=0,035)$, dengan demikian dapat disebutkan terdapat hubungan negatif antara pol asuh autoritatif dengan taraf kecemasan.
\end{abstract}

Kata Kunci: Pola asuh autoriatif,kecemasan, siswa akselerasi

\begin{abstract}
Anxiety is a state of excessive tension is not in place, which is marked by feelings of worry, uncertain or afraid. Anxiety is able to influence health and emotional development, so it plays an important role in someone's life, even more in acceleration class which is always required high achievement. Parenting style adopted by parents determine the ability of adolescents to adapt to a variety of problems. Application of the authoritative parenting style characterized by warmth of parent-child relationship will greatly affect the ability of adolescents to overcome emotional problems.

This study aims to determine the relationship between authoritative parenting style with acceleration students' anxiety level. Subjects in this study were all acceleration students of SMAN 1 Denpasar. The instrument used in this study is the authoritative parenting scale and the scale of anxiety.

The research data were analyzed by using product moment. The correlation coefficient between authoritative parenting style with the anxiety level is $-0.268(\mathrm{p}=0.035)$, thus can be mentioned that there was a negative relationship between authoritative parenting style with anxiety level.
\end{abstract}

Keywords: authoritative parenting style, anxiety, acceleration students 


\section{LATAR BELAKANG}

Kata anxietas atau kecemasan berasal dari bahasa latin, yaitu angere yang memiliki arti tercekik atau tercekat, respon yang ditunjukkan oleh kecemasan biasanya tidak ada kaitannya dengan ancaman yang nyata, hanya saja mampu menjadikan individu tidak dapat bertindak ataupun menarik diri. Kecemasan juga memiliki arti suatu keadaan yang dirasakan oleh individu yaitu tegang yang berlebihan serta tidak pada tempatnya hal tersebut ditandai dengan perasaan khawatir, tidak menentu ataupun takut (Maramis, 2009).

Menurut Kaplan dan Sadock (2010), kecemasan merupakan suatu sinyal yang mampu menyadarkan, dan sinyal tersebut memperingatkan bahwa adanya bahaya yang mengancam serta memungkinkan seseorang untuk mengambil tindakan dalam mengatasi ancaman tersebut. Gangguan kecemasan merupakan gangguan psikologis yang mencakup adanya ketegangan motorik seperti (bergetar, tidak dapat duduk dengan tenang, tidak dapat bersantai), adanya hiperaktivitas seperti (pusing, jantung berdebar cepat, berkeringat) serta adanya harapan-harapan dan pikiran-pikiran yang mendalam (King, 2007). Hal serupa juga dijelaskan oleh (Maramis, 2009) bahwa gejala kecemasan terdiri atas dua komponen yaitu komponen psikis atau mental dan komponen fisik. Komponen psikis yang dimaksud adalah adanya kecemasan itu sendiri seperti halnya rasa khawatir yang berlebihan dan perasaan was-was. Komponen fisik timbul karena adanya keterjagaan yang berlebihan (hyperarousal syndrome) seperti halnya: jantung berdebar, nafas yang cepat sehingga menimbulkan sesak, mulut kering, masalah lambung (maag), tangan serta kaki terasa dingin, dan adanya ketegangan otot (pada pelipis, tengkuk dan punggung).

Berdasarkan penjelasan tersebut dapat dilihat bahwa individu yang memiliki kecemasan mampu mempengaruhi kesehatan, yang akan berdampak pada perkembangan emosinya. Emosi itu sendiri merupakan salah satu aspek psikologis dari individu, baik dalam ranah afektif dan aspek psikologis. Hal ini sangatlah berperan penting dalam kehidupan individu salah satunya pada kehidupan remaja. Pada masa remaja, remaja cenderung tidak menunjukkan ekspresi emosi yang sebenarnya, emosi pada remaja cenderung sangat individual atau subjektif. Hal tersebut tergantung pada kondisi masing-masing remaja, sehingga tidak heran apabila kondisi emosi remaja dapat saja meningkat serta dapat saja berubah dari sebelumnya. Kondisi emosi yang berlangsung secara terus-menerus pada akhirnya dapat memunculkan gangguan emosional (Thalib, 2010).

Menurut Goleman (2002), gangguan emosional dapat mempengaruhi kehidupan mental, hal tersebut bukanlah hal baru lagi untuk para guru, guru terbiasa menangani remaja atau siswa yang mengalami cemas, marah serta depresi. Apabila hal tersebut selalu dirasakan oleh siswa tentunya akan mempengaruhi prestasi serta hasil belajar karena siswa akan kesulian dalam proses belajarnya. Bahkan apabila siswa diketahui cemas berkepanjangan, ditakutkan dapat menyebabkan kecemasan didalam bidang akademik sehingga ada kemungkinan untuk siswa menjadi sering membolos (Rutter, 2008). Terlebih lagi pada siswa akselerasi yang secara metode belajar dan kurikulumnya sangat berbeda dengan siswa kelas reguler dimana siswa akselerasi dituntut untuk berprestasi tinggi maka ada kemungkinan akan mengalami kecemasan tinggi (Hawadi, 2004).

Menurut Maramis (2009), tekanan dapat berasal dari dalam dan dari luar diri individu. Tekanan dari dalam dapat berasal dari cita-cita, norma-norma atau pengharapan tinggi yang ingin dicapai. Apabila hal tersebut dirasakan secara terus-menerus dapat menimbulkan tekanan, sedangkan tekanan dari luar dapat dirasakan siswa yaitu berasal dari guru atau orang tua siswa akselerasi, yang menuntut agar siswa mampu berprestasi dengan nilai akademik yang tinggi dan mampu mempertahankannya.

Akselerasi memiliki arti meloncat kelas, serta mengikuti pelajaran tertentu pada kelas di tingkat atasnya, sedangkan pada model kurikulum, akselerasi memiliki tujuan untuk mempercepat bahan ajar dari yang seharusnya dikuasai oleh siswa saat itu. Misalnya seperti siswa yang duduk dibangku SMP hanya menempuh pendidikan selama dua tahun dan begitu pula dengan siswa SMA. Hal tersebut dikarenakan kecerdasan dan bakat istimewa yang dimiliki oleh siswa tersebut, sehingga ia mampu melanjutkan jenjang yang lebih tinggi dibandingkan teman seusianya. Pada umumnya siswa akselerasi memiliki beban belajar serta tugas-tugas yang lebih kompleks sehingga mendapatkan perhatian lebih dari guru, pembimbing maupun orang tua. Tekanan dan tuntutan yang dirasakan siswa akselerasi merupakan ancaman yang tidak nyata atau samar-samar sehingga tekanan dan tuntutan ini bila tidak mampu diatasi oleh individu atau siswa maka menimbulkan suatu kecemasan terutama pada siswa yang kurang matang emosinya (Kaplan dan Sadock, 2010).

Berdasarkan pengamatan peneliti terhadap siswa yang mengikuti kelas akselerasi, menunjukkan bahwa terdapat beberapa siswa merasa cemas jika dihadapkan dengan beberapa tugas secara bersamaan. Menurut siswa, hal tersebut juga mempengaruhi kegiatan sehari-hari, seperti waktu berkumpul bersama dengan keluarga, jarang bermain dengan teman sebaya karena lebih mengutamakan tugas sekolahnya. Beberapa siswa lainnya menyatakan hal yang berbeda, mereka menganggap tugas-tugas yang diberikan merupakan suatu kewajiban yang harus diselesaikan sehingga mereka tidak merasa terbebani untuk menyelesaikan tugas dengan tepat waktu.

Pernyataan dan keadaan siswa akselerasi yang terdapat di lapangan telah menimbulkan pertanyaan bagi peneliti, "Mengapa ada siswa akselerasi yang merasa cemas, 
sedangkan yang lainnya tidak?". Dari pernyataan tersebut tentunya menggambarkan bahwa kecemasan setiap siswa berbeda. Hal ini sangatlah memerlukan perhatian yang lebih, tidak hanya bagi siswa dan guru, tapi juga bagi orang tua. Sejalan dengan pernyataan Rochmat Wahab (2005), bahwa peranan orangtua dan Pendidik dalam mengoptimalkan potensi anak berbakat akademik sangatlah penting. Ia menyatakan bahwa peran keluarga atau orangtua bagi anak berbakat (siswa akselerasi) merupakan tempat pengasuhan yang terjadi dalam keluarga itu sendiri, sebagai awal dari setiap usaha untuk melakukan bimbingan dan pendidikan, yang nantinya mampu mengoptimalisasi perkembangan anak, serta diakui juga bahwa kehadiran orangtua sangat mempengaruhi kemampuan fisik, sosial, intuisi, kognitif dan emosi pada siswa akselerasi.

Keluarga atau orang tua bagi seorang anak merupakan pendukung utama terkait nilai-nilai kearifan lokal, utamanya dalam pengasuhan anak. Keluarga juga merupakan lingkungan sosial pertama bagi seorang anak. Di dalam keluaraga terjadi proses interaksi antara anak dengan orang tua baik itu dengan ayah dan ibu, yang biasa disebut pola asuh (Thalib, 2010). Pola asuh merupakan interaksi antara anggota keluarga, yang berhubungan dengan ketrampilan pada pengawasan atau monitoring adanya penggunaan disiplin serta hukuman secara efektif, serta pemberian penguatan dalam mendukung perkembangan keterampilan prososial dan juga keterampilan dalam memecahkan masalah (Patterson dalam Thalib, 2010).

Masing-masing orang tua memiliki cara serta kekhasan dalam mengasuh dan mendidik anaknya. Penerapan tipe pola asuh yang berbeda dapat mempengaruhi karakter, sikap, serta cara berpikir anak. Menurut Baumrind (dalam Santrock, 2007) terdapat empat tipe pola asuh, yaitu autoritarian, autoritatif, permisif, dan neglected. Autoritarian adalah cara pengasuhan yang membatasi, menghukum, serta menuntut anak untuk mengikuti perintah-perintah orang tua dan menghormati pekerjaan serta usaha-usaha yang telah dilakukan oleh orang tuanya. Orang tua dengan cara pengasuhan autoritarian akan menetapkan batasan-batasan yang tegas dan tidak memberi kesempatan yang besar kepada anak-anak untuk berbicara. Pola asuh Autoritatif merupakan gaya pengasuhan yang mendorong anak-anak agar mandiri namun masih menetapkan batas-batas dan pengendalian atas tindakan-tindakan mereka. Pengasuhan yang autoritatif diasosiasikan dengan kompetensi sosial yang baik pada anak. Pola Asuh permisif adalah gaya pengasuhan orang tua yang sangat terlibat dalam kehidupan anak-anaknya hanya saja menetapkan sedikit batas serta kendali terhadap mereka. Orang tua dengan cara pengasuhan permisif biasanya akan membiarkan anak-anaknya melakukan apa saja yang mereka inginkan, namun akibatnya anak-anak tidak akan pernah belajar mengendalikan perilaku mereka sendiri dan selalu mengharapkan semua kemauan mereka dituruti. Pola asuh neglected adalah gaya pengasuhan dimana orang tua sangat tidak terlibat dalam kehidupan anak. Tipe ini akan berdampak pada kompetensi sosial yang buruk pada anak, khususnya pada pengendalian diri.

Dari keempat jenis pola asuh yang telah dikemukakan, dapat dilihat bahwa pola asuh yang lebih banyak memiliki dampak positif pada perkembangan anak adalah pola asuh autoritatif, karena orang tua yang menerapkan pola asuh autoritatif akan lebih terbuka, memberikan pertimbangan dan penjelasan yang rasional berkaitan kebijakan yang akan dilaksanakan, serta orang tua memberikan otonomi pada anak tetapi juga dengan disiplin, orang tua memberikan kebebasan tetapi memberikan kontrol, orang tua menunjukan kehangatan dan komunikasi yang baik, namun konsisten dalam pernyataan-pernyataan dan tindakan (Thalib, 2010).

Pengasuhan dengan gaya autoritatif menekankan juga pada kontrol positif, serta pengasuhan autoritatif memberikan kesempatan pada anak agar berperan serta dalam aktivitasaktivitas yang ada, menaruh perhatian terhadap pandangan dan perbedaan individual anak, fleksibel pada aturan-aturan yang telah di sepakati bersama, serta pengasuhan autoritatif memberikan dorongan, membantu anak dalam membuat keputusan dan memecahkan masalahnya sendiri (Thalib, 2010).

Sedangkan menurut Santrock (2007), orang tua dengan pola asuh autoritatif biasanya akan mencapai keseimbangan yang baik pada pengendalian dan otonomi, memberikan peluang pada anak-anaknya serta remaja dalam mengembangkan kemandirian dan memberikan standar, batasan, dan bimbingan yang diperlukan anak. Orang tua juga banyak memberi kesempatan anak untuk berdialog verbal secara bersama dan memberi kesempatan anak-anaknya untuk mengekspresikan pandangan-pandangannya.

Berdasarkan penjelasan tersebut bahwa orang tua dengan pola asuh autoritatif dapat menunjukkan sikap yang hangat pada anak. Orangtua juga memberikan kesempatan pada anak untuk berdialog secara verbal, orang tua autoritatif memberi kesempatan anak untuk mengekspresikan pandangan-pandangannya sehingga beban yang dirasakan oleh anak akan berkurang. Sikap orang tua yang menunjukan penerimaan dan dukungan, nantinya akan mampu mengurangi kecemasan anak.

Dalam kaitannya dengan peran orang tua terhadap penurunan taraf kecemasan Hawadi (2006) mengemukakan bahwa kesediaan orang tua untuk mendengarkan masalah yang disampaikan anak mampu meredakan masalah emosional anak salah satunya kecemasan. Secara tidak disadari apabila orang tua menerapkan hal-hal tersebut, orang tua akan memberikan hal yang positif bagi anaknya serta membangkitkan motivasi 
intrinsik dalam diri anak atau siswa akselerasi, yang dalam hal ini mengalami kecemasan.

Bertolak dari penjelasan tersebut peneiti ingin meneliti " hubungan pola asuh autoriatif dengan taraf kecemasan pada siswa akselerasi di SMA Negeri 1 Denpasar".

\section{METODE}

\section{Hipotesis Penelitian}

Ada hubungan negatif antara pola asuh autoritatif dengan taraf kecemasan siswa akselerasi SMA Negeri 1 Denpasar.

\section{Variabel dan Definisi Operasional}

Variabel bebas pada penelitian ini adalah Pola asuh autoritatif, dan variabel tergantung adalah Taraf kecemasan. Adapun definisi operasional dari masing-masing variabel tersebut :

\section{Pola asuh autoritatif}

kebiasaan orang tua dalam memberikan dukungan dan mengarahkan anak dengan menekankan pentingnya :

a. Berpikir rasional dan tertuju pada pokok persoalan

b. Mengajarkan anaknya untuk mendengarkan pendapat orang lain dan menyatakan pendapatnya sendiri

c. Memberi kontrol yang tegas pada anak-anaknya saat ada perselisihan pendapat dan orang tua tentunya tidak menuntut anak akan batasan-batasan yang ada

d. Memberikan kesempatan pada anak-anaknya untuk berdialog verbal, sehingga diharapkan anak mampu menyampaikan hal-hal apa saja yang dirasakan oleh anak. Pola asuh autoritatif diukur menggunakan skala pola asuh autoritatif.

\section{Taraf kecemasan}

Kecemasan merupakan suatu sinyal yang ditandai oleh adanya suatu ancaman berbahaya, perasaan takut serta kekhawatiran yang tidak menyenangkan sehingga dapat mempengaruhi gejala otonomik (seperti nyeri kepala, berkeringat, jantung berdebar, rasa kaku pada dada serta gangguan lambung ringan). Taraf kecemasan diukur dengan skala kecemasan

\section{Responden dan Tempat Penelitian}

Populasi dalam penelitian ini adalah siswa akselerasi yang bersekolah di SMA Negeri 1 Denpasar. Oleh karena jumlah kelas akselerasi sangat terbatas yaitu 62 orang, maka semua populasi digunakan subjek penelitian, sehingga dapat disebutkan sampel dalam penelitian ini sampel jenuh.

Adapun kriteria inklusi subjek penelitian:

1. Merupakan siswa yang mengikuti program/kelas akselerasi

2. Bersekolah di SMA negeri 1 Denpasar

3. Bersedia untuk menjadi subjek penelitian

4. Memiliki IQ minimal 130 (sesuai dengan standarisasi sekolah )

\section{Alat ukur}

Alat ukur pada penelitian ini menggunakan dua skala yaitu skala pola asuh autoritatif dan skala kecemasan. Skala pola asuh autoritatif dalam penelitian ini menggunakan skala yang disusun oleh Rustika (2014) yang disusun berdasarkan konsep Baumrid (2005) dan Cross (2009). Skala ini telah diuji taraf reabilitasnya dengan teknik Cronbach Alpha dengan koefisien reabilitasnya 0,901 , sedangkan uji validitas dengan teknik analisis faktor konfirmatori dan skala valid, sehingga tidak perlu lagi dilakukan uji validitas dan reabilitas. Jumlah aitem skala pola asuh autoritatif 23 aitem. Sedangkan skala kecemasan disusun sendiri oleh peneliti berdasarkan aspekaspek yang disebutkan Hawari (2014). Pada awalnya skala kecemasan terdiri dari 30 aitem, setelah dilakukan uji validitas dan reliabilitas terdapat 5 aitem yang gugur sehingga jumlah aitem skala kecemasan menjadi 25, koefisien korelasi aitemtotal berkisar antara 0,381 hingga 0,649. Koefisien reliabilitas skala kecemasan adalah 0,897 . Skala pola asuh autoritatif dan kecemasan disajikan dalam bentuk pernyataan favorable dan unfavorable, terdapat 4 pilihan jawaban pernyataan yaitu: Sangat Tidak Setuju (STS), Tidak Setuju (TS), Setuju (S), Sangat Setuju (SS).

\section{Teknik Analisis Data}

Untuk menganalisis data penelitian yang telah diperoleh peneliti menggunakan teknik korelasi product moment dari Pearson dengan bantuan program statistik Statistical Package for Social Science (SPSS) versi 15.

\section{HASIL PENELITIAN}

\section{Deskripsi Data Penelitian}

Tabel 1.

Deskripsi statistik data penelitian

\begin{tabular}{|c|c|c|c|c|c|c|c|c|}
\hline & $\mathrm{N}$ & $\begin{array}{l}\text { Mean } \\
\text { teoretis }\end{array}$ & $\begin{array}{l}\text { Mean } \\
\text { empiris }\end{array}$ & $\begin{array}{l}\text { Sd } \\
\text { Teoritis }\end{array}$ & $\begin{array}{l}\text { Sd } \\
\text { Empiris }\end{array}$ & $\begin{array}{l}\text { Sebaran } \\
\text { teoritis }\end{array}$ & $\begin{array}{l}\text { Sebaran } \\
\text { empiris }\end{array}$ & Nilai T \\
\hline PAA & 62 & 57,5 & 76,93 & 11,5 & 10,01 & $23-92$ & $37-92$ & $\begin{array}{l}15,289 \\
(p=0,000)\end{array}$ \\
\hline KC & 62 & 62,5 & 52,59 & 12,5 & 10,70 & $25-100$ & $25-72$ & $\begin{array}{l}-7,287 \\
(p=0,000)\end{array}$ \\
\hline
\end{tabular}


Perbedaan mean teoretis dan mean empiris variabel pola asuh autoritatif sebesar 19,43. Mean empiris lebih tinggi dari mean teoretis, dengan nilai t sebesar 15,289 ( $\mathrm{p}=0,000)$, hal tersebut menunjukkan adanya perbedaan yang signifikan antara mean empiris dan mean teoritis pada variabel pola asuh autoritatif. Rentang skor subjek penelitian antara 37 hingga 92. Berdasarkan penyebaran frekuensi 96,77 \%. subjek penelitian berada di atas mean teoretis $(57,5)$. Hal ini menunjukkan bahwa taraf pola asuh autoritatif orang tua subjek penelitian tergolong tinggi

Perbedaan mean teoretis dan mean empiris variable kecemasan sebesar -9,90. Mean empiris lebih rendah dari mean teoretis, dengan nilai t sebesar -7,287 ( $\mathrm{p}=0,000)$, hal tersebut menunjukkan adanya perbedaan yang signifikan antara mean empiris dan mean teoritis pada variabel kecemasan. Rentang skor subjek penelitian antara 25 hingga 72. Berdasarkan penyebaran frekuensi 16,12\% subjek penelitian berada di atas mean teoretis (62,5), hal ini menunjukkan bahwa kecemasan pada siswa tinggi sedangkan sisanya $83,88 \%$ subjek memiliki taraf kecemasan yang rendah.

Uji Asumsi

Tabel 2.

Hasil uji normalitas

\begin{tabular}{ccc}
\hline & PAA & KC \\
\hline Kolmogorov-Sminov Z & 0,743 & 0,982 \\
Asymp. Sig. (2-tailed) & 0,639 & 0,289 \\
\hline
\end{tabular}

Hasil uji normalitas pada penelitian ini menggunakan kolmogorov-Smirnov. Berdasarkan tabel 2 dapat diketahui bahwa Uji Normalitas sebaran data pada variabel pola asuh, mempunyai nilai signifikansi dengan probabilitas (p) 0,639 yang artinya nilai probalilitas di atas 0,05 ( $p>0,05)$. Hal ini menunjukkan bahwa sebaran data pada variabel pola asuh autoritatif bersifat normal, sedangkan Uji Normalitas sebaran data pada variabel kecemasan memiliki nilai signifikansi dengan probabilitas (p) 0,289 yang artinya probalilitas di atas 0,05 ( $\mathrm{p}>0,05$ ) sehingga hal ini menunjukkan bahwa sebaran data pada variabel kecemasan bersifat normal.

Tabel 3

Hasil Uji Linearitas

\begin{tabular}{lll|c|c}
\hline & & $F$ & Signifikansi \\
\hline$P A A^{*} K C$ & Between & (Combined) & 3,296 &, 001 \\
& Group & Linearity & 9,346 &, 005 \\
& & Deviation from & 3,088 &, 001 \\
& linearity & & \\
\hline
\end{tabular}

Hasil uji Linearitas menunjukkan bahwa hubungan variabel pola asuh autoritatif dan variabel kecemasan adalah linear karena memiliki probabilitas (p) sebesar 0,005 atau memiliki taraf signifikansi untuk linearitas lebih kecil dari $0,05(\mathrm{p}<0,05)$ sehingga dikatakan bahwa hubungan antara skor variabel pola asuh autoritatif dan variabel kecemasan menunjukkan adanya hubungan yang linier.

Berdasarkan uji normalitas dan uji linearitas yang telah dilakukan diperoleh hasil bahwa data penelitian bersifat normal dan linear sehingga analisis korelasi product moment dapat dilakukan.

\section{Uji Hipotesis}

Berikut merupakan hasil analisis data dengan teknik product moment variabel pola asuh autoritatif dengan variabel kecemasan:

Tabel 4.

Hasil analisis data dengan teknik product moment

\begin{tabular}{llrr}
\hline & & Pola asuh & Kecemasan \\
\hline Pola asuh & Pearson Correlation & 1 &,$- 268\left(^{*}\right)$ \\
& Sig. (2-tailed) & &, 035 \\
\multirow{4}{*}{ Kecemasan } & $\mathrm{N}$ & 62 & 62 \\
& Pearson Correlation &,$- 268\left(^{*}\right)$ & 1 \\
& Sig. (2-tailed) &, 035 & 62 \\
& $\mathrm{~N}$ & 62 & 6 \\
\hline
\end{tabular}

Hasil analisis data menunjukan $r=-0,268(0,035)$, karena nilai Sig (2-tailed) $<0,05$ maka disimpulkan terdapat hubungan yang negatif antara pola asuh autoritatif dengan kecemasan siswa akselerasi.

\section{PEMBAHASAN DAN KESIMPULAN}

Hasil analisis data menunjukkan koefisien korelasi antara pola asuh autoritatif dengan kecemasan sebesar -0,268 ( $\mathrm{p}=0,035)$ Hal ini menunjukkan bahwa hubungan pola asuh autoritatif dengan taraf kecemaan adalah hubungan yang berlawanan/ tidak searah. Dengan demikian dapat disebutkan jika terjadi peningkatan taraf pola asuh autoritatif maka akan terjadi penurunan taraf kecemasan.

Hasil penelitian sejalan dengan pendapat Hawadi (2004), yang menyatakan bahwa orang tua memiliki peran yang sangat penting dalam meningkatkan kematangan emosional anak, lebih-lebih lagi pada orang tua yang mempunyai anak masuk program akselerasi yang menghadapi banyak tuntutan, seperti tuntutan berprestasi tinggi, untuk selalu mempertahankan prestasi yang sudah dicapai dan sebagainya. Sehingga orangtua yang kurang mampu menjalin hubungan hangat dengan anak diharapkan mengubah gaya pengasuhannya menjadi gaya autoritatif, memiliki waktu luang pada saat anak membutuhkan orangtua disampingnya, mau mendengarkan masalah- masalah yang disampaikan anak.

Hasil penelitian ini juga sejalan dengan hasil penelitian Rustika (2014) yang menunjukkan peran pola asuh autoritatif sangat besar terhadap perkembangan kecerdasan emosional anak. Anak-anak yang diasuh dengan pola asuh autoritatif akan lebih mampu mengenali gejolak emosi yang dirasakan, serta lebih mampu mengendalikan gejolak emosi 
yang dialami, sehingga pada waktu anak mengalami perasaan cemas akan lebih mampu meredakan perasaan cemas tersebut. Dari hasil kategorisasi data penelitian variabel pola asuh autoritatif menunjukkan bahwa subjek yang termasuk dalam kategori tinggi pola asuh autoritatif sebanyak 49 orang atau sekitar $79 \%$, subjek yang termasuk kategori sedang berjumlah 12 orang atau sekitar $19,4 \%$ dan yang masuk dalam kategorisasi rendah berjumlah 1 orang atau sekitar 1,6\%, hal ini menunjukkan bahwa mayoritas atau sebagian besar orang tua siswa akselerasi menerapkan pola asuh autoritatif pada anak-anaknya, apabila dilihat berdasarkan data tambahan untuk pendidikan orangtua dari siswa akselerasi menunjukkan bahwa, mayoritas pendidikan ayah adalah sarjana, begitu juga pendidikan ibu mayoritas sarjana. Berdasarkan data pendidikan orangtua menunjukkan bahwa orangtua siswa akselerasi sebagian besar merupakan lulusan sarjana sehinga dapat menggambarkan bahwa orangtua siswa akselerasi memiliki intelektual tinggi. Orangtua mampu menerima berbagai informasi mengenai cara pengasuhan yang tepat dan efektif untuk anak-anaknya, salah satunya memahami bagaimana penerapan pola asuh autoritatif yang baik untuk anaknya.

Adapun hasil kategorisasi data penelitian variabel kecemasan menunjukkan jumlah subjek yang termasuk dalam kategori rendah adalah sebanyak 24 orang atau sekitar $38,7 \%$, subjek yang termasuk kategori sedang berjumlah 38 orang atau sekitar 61,3\% sedangkan subjek pada kategorisasi kecemasan tinggi tidak ada atau $0 \%$, hal ini menunjukkan bahwa kecemasan yang di rasakan oleh siswa akselerasi cenderung pada kategori sedang. Dengan demikian dapat disebutkan terdapat beberapa siswa akselerasi yang mengalami perasaan cemas. Hasil tersebut sesuai dengan penelitian yang dilakukan oleh Terman (dalam Semiawan, 1997) yang menyatakan bahwa pada umumnya anak berbakat sering mengalami kecemasan, stres dan beberapa diantaranya siswa tersebut tidak mampu mengatasi kecemasan dan stres yang dihadapinya.

Selain itu peneliti juga membandingkan serta melihat pola asuh autoritatif ditinjau dari jenis kelamin siswa akselerasi di SMA Negeri 1 Denpasar. Analisis yang dilakukan peneliti menggunakan Independent sample t-test dan didapatkan skor Sig menunjukkan angka 0,032 yang berarti angka signifikansi di bawah $<0,05$. Hal tersebut menunjukkan bahwa ada perbedaan antara pola asuh autoritatif dilihat berdasarkan jenis kelamin siswa akselerasi, pada tabel statistik menunjukkan bahwa Mean dari anak perempuan menunjukkan 77,42 sedangkan anak laki-laki 76,45 maka dapat dilihat bahwa penerapan pola asuh autoritatif yang tinggi lebih diterapkan dan dirasakan pada anak perempuan. Hal tersebut sejalan dengan Brody dan Hall (dalam Goleman, 1998) yang menyatakan bahwa anak perempuan lebih terampil dalam berbahasa dibandingkan anak laki-laki, sehingga anak perempuan lebih mampu mengutarakan perasaan-perasaanya dan lebih terampil dalam mengutarakan kata-kata, hal tersebut dikaitkan dengan bagaimana anak perempuan yang mampu berbagi perasaanya pada orang tua dengan pola asuh autoritatif, dimana mereka diberikan kesempatan untuk menjelaskan dan menceritakan perasaan yang sedang dihadapi pada orang tua mereka, lain halnya dengan anak laki-laki yang cenderung kurang mampu mengutarakan perasaannya pada orang tua.

Apabila ditinjau dari urutan kelahiran peneliti mendapatkan jumlah anak sulung sebanyak 26 orang, sedangkan untuk anak tunggal, anak tengah dan anak bungsu berada dibawah dari jumlah tersebut. Dengan demikian dapat disebutkan bahwa kelas akselerasi di dominasi oleh anak sulung, hal tersebut sejalan dengan pemaparan Hadibroto, Alam, Suryaputra, \& Olivia (2002), yang menyatakan anak sulung merupakan anak yang mampu mencapai kesuksesan tinggi dalam hal yang ditekuninya, anak sulung umumnya memiliki IQ yang sangat tinggi mereka juga mampu meraih sukses terbaik dalam pendidikan dan kemungkinan kecil akan mengalami kegagalan pada bidang akademis, anak sulung juga memiliki motivasi dan keinginan yang tinggi untuk meraih sukses dan mereka juga menunjukkan penguasaan pengetahuan yang sangat baik. Berdasarkan penjelasan tersebut maka sesuai dengan karakter siswa akselerasi bahwa siswa akselerasi memiliki IQ yang tinggi, siswa akselerasi memiliki kemampuan yang terbaik dalam pendidikannya serta kemungkinan kecil mengalami kegagalan.

Dari hasil dan pembahasan yang telah disampaikan dapat dikemukakan beberapa saran:

Bagi orang tua sebaiknya lebih memahami konsep pola asuh autoritatif dalam mengasuh anaknya, terutama bagi orang tua yang anaknya mengikuti kelas akselerasi. Disamping itu rang Tua diharapkan memahami hal apa yang sangat dibutuhkan anak akselerasi, terutama pada kebutuhan psikologis seperti kasih sayang, penghargaan dan perhatian pada anaknya, sehingga anak mampu dengan cepat mengatasi permasalahan emosional yang ia hadapi.

Guru diharapkan mampu memahami kebutuhankebutuhan psikologis kepada siswa akselerasi, sehingga anak didik mampu berprestasi dengan optimal. Selain memberikan bahan pelajar diharapkan juga memberikan respon positif terhadap usaha yang ditunjukkan siswa akselerasi, seperti pemberian penghargaan, perhatian dan menjadi pendengar yang baik bagi anak didiknya

Apabila menemukan siswa akselerasi yang mengalami cemas, pihak sekolah sebaiknya melakukan pengarahan kepada guru pembimbing siswa akselerasi serta orangtua siswa akselerasi agar bersama-sama memperhatikan hal-hal apa saja yang dibutuhkan siswa, sehingga guru dan orangtua tetap menjalin komunikasi yang baik terhadap penangan khusus untuk siswa akselerasi. Sekolah juga 
melakukan kegiatan rutin yaitu konseling mengenai perkembangan siswa akselerasi pada orangtua siswa sehingga sekolah menjadi paham, mengenai perkembangan anak didiknya khususnya siswa akselerasi, serta penanganan yang tepat apabila siswa memiliki permasalahan dalam belajar.

Siswa akselerasi diharapkan berani mengutarakan perasaan-perasaannya kepada orang tua dan guru pada waktu menghadapi permasalahan, sehingga mendapatkan dukungan dari mereka. Labeling yang diberikan sebagai orang yang memiliki kemampuan lebih, jangan membuat diri over confident atau sebaliknya menjadi tertekan/ stres. Siswa diharapkan mampu bersosialisasi baik dengan lingkungan sekolahnya sehingga secara tidak langsung siswa akselerasi akan mendapat dukungan dari lingkungannya sehingga masalah emosionalnya dapat diatasi.

Bagi peneliti berikutnya diharapkan menggunakan lebih banyak sampel siswa akselerasi dan mencari sampel siswa akselerasi dari beberapa sekolah yang lebih luas.

\section{DAFTAR PUSTAKA}

Baumrind, D.(2005). Patterns of Parental authority and adolescent autonomy. New Directions for child \& Adolescent Development.

Cross,(2009).Parenting Style. University of California, Berkeley.

Goleman, D. (1998). Working with emotional intelligence. Bantam Dell

Goleman, D. (2002). Emotional Intelligence Kecerdasan Emosional Mengapa EI lebih penting daripada IQ. Jakarta: PT. Gramedia Pustaka Utama

Harold I. Kaplan, M.B. (2010). Kaplan dan Sadock Sinopsis Psikiatri ilmu pengetahuan perilaku Psikiatri Klinis ( jilid dua). Ciputat-Tangrang : Binarupa Aksara Publisher.

Hawari, D.(2013). Manajemen stress cemas dan depresi. Jakarta: Badan Penerbit FKUI.

Hawadi, R. A. (2004). AKSELERASI A-Z Informasi Program Percepatan Belajar dan Anak Berbakat Intelektual. Jakarta: PT Grasindo.

Iwan Hadibroto, S. A. (2002). Misteri perilaku anak sulung, tengah, bungsu,dan tunggal mengenali konsep urutan kelahiran untuk memahami orang lain dan diri sendiri. Jakarta: PT Gramedia Pustaka.

King, L.A. (2007). Psikologi Umum Sebuah Pandangan Apresiatif. Salemba Humanika.
Maramis, W.F. (2009). Catatan ilmu kedokteran jiwa edisi 2. Surabaya: Pusat Penerbitan dan Percetakan (AUP).

Michael Rutter, D.B. (2008). Rutter's Child and Adolescent Psychiatry Fifth edition. WILEY-BLACKWEL

Rustika, I.M. (2014). Faktor-faktor yang mempengaruhi prestasi akademik pada remaja (Disertasi tidak dipublikasikan). Yogyakarta. Fakultas Psikologi; Universitas Gadjah Mada

Santrock,J. (2007). Remaja jilid 2. Erlangga

Semiawan,C.(1997). Perspektif pendidikan anak berbakat. Jakarta: PT Gramedia Widiasarana Indonesia

Syamsul Bachri Thalib, M. (2010). Psikologi Pendidikan Berbasis Analisis Empiris Aplikatif. Jakarta: Fajar Interpratama Offset.

Wahab,R. (2005). Peranan orangtua dan Pendidik dalam mengoptimalkan potensi anak berbakat akademik. Seminar Keberbakatan. (hal. 1-14). Semarang: Universitas Diponegoro 